\title{
Te Mere Pounamu
}

The book "The Tail of the Fish" was publised in 1968 and written by a Te Aupouri kuia, Matire Kereama (nee: Hoeft) of the far north of Aotearoa, New Zealand. I grew up with this book as my grandmother would read the stories to me at bedtime. Although my comprehension of each story was very vague and unrelatable to my life at that time, today, I find myself totally absorbed by the historical content and knowledge encapsulated in each chapter.

I completed a Masters of Applied Indigenous Knowledge at Te Wananga o Aotearoa in 2017, entitled; Tales of the singing fish: He tangi wairua. I compsed twelve waiata (Maori songs) of which ten of the waiata was information extracted from ten chapters of the book. The other two waiata were composed specifically for my people of the Te Rarawa tribe, namely, Ahipara.

The great ancestress, Waimirirangi, who is known as 'Queen of Ngā Puhi', had seven children from whom the northern Māori tribes are descended. Her husband was Kaharau, twice removed from Rāhiri another great Ngā Puhi. In the days of the gum diggers, an aged Chief named Reone Ngāruhe and his two young nieces remained at Hauturu near Whangapē while the rest of the people went north. As the day was warm, the old man wanted to go to the bush above his home to look for wild berries. The girls who liked roaming round the bush went with him. They came to a cliff and one of the girls wondering what grew down there decided to investigate. It was a difficult climb and she was about to give up when she noticed something in one of the cracks of the cliff. 
Calling to her uncle to come and see she pointed to a narrow hole exclaiming, "look in there in that hole". The old man looked and saw and then he became serious and told the girls to go home while he picked up the thing which they had seen. Reone took the object down to the creek and washed it clean. I believe that he also said some prayers over it. Then he took it home, wrapped it up carefully and put it away to await the return home of the people. The people look at the object in amazement as it was a greenstone (pounamu) mere (weapon). They knew it to be a particularly valuable one which a chief had hidden away many years before when a raiding party had visited the district. The mere had belonged to Waimirirangi.

\author{
Waimirirangi \\ He aroha he wawata \\ Kei ngaro o tātou tātai tūpuna \\ I tuhi ai au i ènei mea katoa \\ E kī ana hoki rātou \\ He tātai tāngata \\ Ngaro noa ngaro noa \\ He tātai whetū mau tonu \\ Mau tonu \\ Noho mai ra e te iwi \\ Kia mau kia $\bar{u}$ \\ Ki tō tātou Māoritanga
}

